Review

\title{
Emerging Biomarkers for the Selection of Advanced NSCLC-Affected Immunotherapy Patients
}

\author{
Luigi Della Gravara $\left.{ }^{1}{ }^{(}\right)$, Ciro Battiloro ${ }^{2}$, Antonietta Letizia ${ }^{2}$, Rosa Cantile ${ }^{2}$, Vito D'Agnano ${ }^{3}$, Giacomo Sica ${ }^{4}$ \\ and Danilo Rocco ${ }^{2, *}$ \\ 1 Department of Experimental Medicine, University of Campania “Luigi Vanvitelli”, 81100 Naples, Italy; \\ luigidellagravara@gmail.com \\ 2 Department of Pulmonary Oncology, AORN dei Colli Monaldi, 80131 Naples, Italy; ciro.battiloro@tin.it (C.B.); \\ tonialetizia@libero.it (A.L.); rosacantile@gmail.com (R.C.) \\ 3 Department of Translational Medical Sciences, University of Campania "Luigi Vanvitelli", 81100 Naples, Italy; \\ vito.dagnano@studenti.unicampania.it \\ 4 Department of Radiology, AORN dei Colli Monaldi, 80131 Naples, Italy; gsica@sirm.org \\ * Correspondence: danilorocc@yahoo.it
}

check for updates

Citation: Della Gravara, L.; Battiloro, C.; Letizia, A.; Cantile, R.; D'Agnano,

V.; Sica, G.; Rocco, D. Emerging

Biomarkers for the Selection of

Advanced NSCLC-Affected

Immunotherapy Patients. J. Mol.

Pathol. 2021, 2, 197-206. https://

doi.org/10.3390/jmp2020017

Academic Editors: Giuseppe Banna and Maria D. Lozano

Received: 30 April 2021

Accepted: 7 June 2021

Published: 10 June 2021

Publisher's Note: MDPI stays neutral with regard to jurisdictional claims in published maps and institutional affiliations.

Copyright: (c) 2021 by the authors. Licensee MDPI, Basel, Switzerland. This article is an open access article distributed under the terms and conditions of the Creative Commons Attribution (CC BY) license (https:// creativecommons.org/licenses/by/ $4.0 /)$.

\begin{abstract}
Immunotherapy in the form of ICIs has revolutionized advanced NSCLC treatment algorithms, with ICI-containing combination treatments being the latest addition to approved regimens. However, PD-L1 still represents the only routinely assessed and validated biomarker apart from genetic drivers testing, impairing our capacity to personalize and guide treatment. Therefore, this paper aims to analyze the most promising emerging predictive biomarkers that could help us in the near future to select patients more effectively.
\end{abstract}

Keywords: advanced NSCLC; immunotherapy; predictive biomarkers; PD-L1; TMB; TILS; NLR; microbiome; IL-8

\section{Immunotherapy for the Treatment of Advanced NSCLC}

While for years, chemotherapy has represented the only major therapy for advanced NSCLC (non-small cell lung cancer) treatment [1-4], as of today, immunotherapy in the form of immune checkpoint inhibitors (ICIs) represents one of the cornerstones of advanced NSCLC treatment. ICIs exert their activity by binding coinhibitory receptors (e.g., PD-1, CTLA-4) or ligands (e.g., PD-L1) in the context of immune checkpoints, thus preventing T-cell deactivation and T-cell apoptosis. [5,6] Four ICIs are currently FDA- (US Food and Drug Administration) and EMA (European Medicines Agency)-approved and recommended by international guidelines for this subset of patients: nivolumab, pembrolizumab, atezolizumab and ipilimumab. These agents are employed both as single agents and in combination with chemotherapy and/or other ICIs and both in the first and in the second line setting. [7-9] (Table 1).

Nivolumab is FDA-approved in association with ipilimumab for naïve squamous and nonsquamous patients without genetic drivers with PD-L1 expression levels $\geq 1 \%$ and is FDA- and EMA-approved in combination with ipilimumab and two cycles of platinum-based doublet chemotherapy for naïve squamous and nonsquamous patients without genetic drivers; moreover, it is also FDA- and EMA-approved in a second line setting for squamous and nonsquamous patients without genetic drivers progressing after platinum-based chemotherapy [10-12].

Pembrolizumab is FDA-approved in monotherapy for naïve squamous and nonsquamous patients without genetic drivers with PD-L1 expression levels $\geq 1 \%$, FDA- and EMAapproved for naïve squamous and nonsquamous patients without genetic drivers with PD-L1 expression levels $\geq 50 \%$, FDA- and EMA-approved in association to cis/carboplatin + pemetrexed for naïve nonsquamous patients without genetic drivers and FDA- and 
EMA-approved in combination to carboplatin + (nab)paclitaxel for naïve squamous patients without genetic drivers; furthermore, it is also FDA- and EMA-approved in a second line setting for squamous and nonsquamous patients without genetic drivers with PD-L1 expression levels $\geq 1 \%$ progressing after platinum-based chemotherapy [13-16].

Atezolizumab is FDA-approved in monotherapy for naïve squamous and nonsquamous patients without genetic drivers with PD-L1 expression levels $\geq 50 \%$ or PD-L1 stained tumor-infiltrating immune cells (IC) $\geq 10 \%$, FDA- and EMA-approved in combination to carboplatin + (nab) paclitaxel + bevacizumab for naïve nonsquamous patients without genetic drivers and FDA- and EMA-approved in combination to carboplatin + nab-paclitaxel for naïve nonsquamous patients without genetic drivers; in addition, it is FDA- and EMAapproved in a second line setting for squamous and nonsquamous patients without genetic drivers progressing after platinum-based chemotherapy [17-20].

Table 1. Currently FDA-approved and international guidelines-recommended ICIs for the treatment of advanced NSCLC.

\begin{tabular}{|c|c|c|c|c|c|}
\hline Drug & PD-L1 Test & $\begin{array}{l}\text { Line of } \\
\text { Treatment }\end{array}$ & Subset of Patients & Regimen & Pivotal Trial/s \\
\hline $\begin{array}{l}\text { Nivolumab } \\
\text { (Anti PD-1 ICI) }\end{array}$ & $\begin{array}{l}\text { PD-L1 IHC 28-8 } \\
\text { pharmDx * }\end{array}$ & First-line & $\begin{array}{l}\text { Naïve squamous and } \\
\text { nonsquamous patients without } \\
\text { genetic drivers with PD-L1 } \\
\text { expression levels } \geq 1 \%\end{array}$ & $\begin{array}{c}\text { Nivolumab } \\
+ \\
\text { Ipilimumab } \\
\text { (Anti CTLA-4 ICI) }\end{array}$ & CheckMate 227 \\
\hline $\begin{array}{c}\text { Nivolumab } \\
\text { (Anti PD-1 ICI) }\end{array}$ & $\begin{array}{l}\text { PD-L1 IHC 28-8 } \\
\text { pharmDx * }\end{array}$ & First-line & $\begin{array}{l}\text { Naïve squamous and } \\
\text { nonsquamous patients without } \\
\text { genetic drivers }\end{array}$ & $\begin{array}{c}\text { Nivolumab } \\
+ \\
\text { Ipilimumab } \\
\text { (Anti CTLA-4 ICI) } \\
+ \\
\text { Two cycles of } \\
\text { platinum-based } \\
\text { doublet } \\
\text { chemotherapy }\end{array}$ & CheckMate 9LA \\
\hline $\begin{array}{c}\text { Nivolumab } \\
\text { (Anti PD-1 ICI) }\end{array}$ & $\begin{array}{l}\text { PD-L1 IHC 28-8 } \\
\text { pharmDx * }\end{array}$ & Second-line & $\begin{array}{l}\text { Squamous and nonsquamous } \\
\text { patients without } \\
\text { genetic drivers } \\
\text { progressing after } \\
\text { platinum-based chemotherapy }\end{array}$ & $\begin{array}{l}\text { Nivolumab } \\
\text { monotherapy }\end{array}$ & $\begin{array}{l}\text { CheckMate } 017 \\
\text { CheckMate } 057\end{array}$ \\
\hline $\begin{array}{l}\text { Pembrolizumab } \\
\text { (Anti PD-1 ICI) }\end{array}$ & $\begin{array}{l}\text { PD-L1 IHC 22C3 } \\
\text { pharmDx * }\end{array}$ & First-line & $\begin{array}{l}\text { Naïve squamous and } \\
\text { nonsquamous patients without } \\
\text { genetic drivers with PD-L1 } \\
\text { expression levels } \geq 1 \%\end{array}$ & $\begin{array}{l}\text { Pembrolizumab } \\
\text { monotherapy }\end{array}$ & KEYNOTE-042 \\
\hline $\begin{array}{l}\text { Pembrolizumab } \\
\text { (Anti PD-1 ICI) }\end{array}$ & $\begin{array}{l}\text { PD-L1 IHC 22C3 } \\
\text { pharmDx * }\end{array}$ & First-line & $\begin{array}{c}\text { Naïve } \\
\text { nonsquamous } \\
\text { patients without } \\
\text { genetic drivers }\end{array}$ & $\begin{array}{c}\text { Pembrolizumab } \\
+ \\
\begin{array}{c}+ \\
\text { Cis/carboplatin } \\
+\end{array} \\
\text { Pemetrexed } \\
\text { Pembrolizumab }\end{array}$ & KEYNOTE-189 \\
\hline $\begin{array}{l}\text { Pembrolizumab } \\
\text { (Anti PD-1 ICI) }\end{array}$ & $\begin{array}{l}\text { PD-L1 IHC 22C3 } \\
\text { pharmDx * }\end{array}$ & First-line & $\begin{array}{c}\text { Naïve squamous patients } \\
\text { without } \\
\text { genetic drivers }\end{array}$ & $\begin{array}{c}+ \\
\text { Carboplatin } \\
+ \\
(\mathrm{Nab}) \text { paclitaxel }\end{array}$ & KEYNOTE-407 \\
\hline $\begin{array}{l}\text { Pembrolizumab } \\
\text { (Anti PD-1 ICI) }\end{array}$ & $\begin{array}{l}\text { PD-L1 IHC 22C3 } \\
\text { pharmDx * }\end{array}$ & Second-line & $\begin{array}{l}\text { Squamous and nonsquamous } \\
\text { patients without } \\
\text { genetic drivers with PD-L1 } \\
\text { expression levels } \geq 1 \% \\
\text { progressing after } \\
\text { platinum-based chemotherapy }\end{array}$ & $\begin{array}{l}\text { Pembrolizumab } \\
\text { monotherapy }\end{array}$ & KEYNOTE-010 \\
\hline $\begin{array}{l}\text { Atezolizumab } \\
\text { (Anti PD-L1 ICI) }\end{array}$ & $\begin{array}{l}\text { Ventana PD-L1 } \\
\quad(\operatorname{sp} 142) *\end{array}$ & First-line & $\begin{array}{l}\text { Naïve squamous and } \\
\text { nonsquamous patients without } \\
\text { genetic drivers with PD-L1 } \\
\text { expression levels } \geq 50 \%\end{array}$ & $\begin{array}{l}\text { Atezolizumab } \\
\text { monotherapy }\end{array}$ & IMpower110 \\
\hline $\begin{array}{l}\text { Atezolizumab } \\
\text { (Anti PD-L1 ICI) }\end{array}$ & $\begin{array}{l}\text { Ventana PD-L1 } \\
(\operatorname{sp} 142) *\end{array}$ & First-line & $\begin{array}{l}\text { Naïve nonsquamous patients } \\
\text { without genetic drivers }\end{array}$ & $\begin{array}{c}\text { Atezolizumab } \\
+ \\
\text { Carboplatin } \\
+ \\
\text { Nab-paclitaxel }\end{array}$ & IMpower130 \\
\hline
\end{tabular}


Table 1. Cont.

\begin{tabular}{|c|c|c|c|c|c|}
\hline Drug & PD-L1 Test & $\begin{array}{l}\text { Line of } \\
\text { Treatment }\end{array}$ & Subset of Patients & Regimen & Pivotal Trial/s \\
\hline $\begin{array}{l}\text { Atezolizumab } \\
\text { (Anti PD-L1 ICI) }\end{array}$ & $\begin{array}{l}\text { Ventana PD-L1 } \\
\quad(\text { sp142) * }\end{array}$ & First-line & $\begin{array}{l}\text { Naïve nonsquamous patients } \\
\text { without genetic drivers }\end{array}$ & $\begin{array}{c}\text { Atezolizumab } \\
+ \\
\text { Carboplatin } \\
+ \\
\text { (Nab)paclitaxel } \\
+ \\
\text { Bevacizumab }\end{array}$ & Impower150 \\
\hline $\begin{array}{l}\text { Atezolizumab } \\
\text { (Anti PD-L1 ICI) }\end{array}$ & $\begin{array}{l}\text { Ventana PD-L1 } \\
\quad(\text { sp142) * }\end{array}$ & Second-line & $\begin{array}{c}\text { Squamous and nonsquamous } \\
\text { patients without } \\
\text { genetic drivers with } \mathrm{PD}-\mathrm{L} 1 \\
\text { expression levels } \geq 1 \% \\
\text { progressing after } \\
\text { platinum-based chemotherapy }\end{array}$ & $\begin{array}{l}\text { Atezolizumab } \\
\text { monotherapy }\end{array}$ & $\begin{array}{c}\text { OAK } \\
\text { POPLAR }\end{array}$ \\
\hline
\end{tabular}

* It is worth mentioning that, while the PD-L1 IHC 22C3 pharmDx and the PD-L1 IHC 28-8 pharmDx tests present a very high concordance, the same does not apply to the ventana PD-L1 (sp142), due to its different staining properties.

\section{Currently Available Biomarkers for the Selection of Advanced NSCLC-Affected Immunotherapy Patients: PD-L1}

PD-L1 (programmed death-1 ligand; also known as CD279 or B7-H1) is a ligand expressed on the surface of antigen presenting cells (APCs), that is to say macrophages, $B$ cells and dendritic cells and on the surface of tumor cells. The binding of PD-L1 to its receptor PD-1 (programmed death 1), expressed on the surface of activated T-cells, causes T-cells deactivation and apoptosis [21,22].

As the above-mentioned data show, apart from genetic drivers testing, up to this date PD-L1 represents the only validated predictive biomarker routinely evaluated in order to stratify patients and to guide the treatment choice in relation to ICI treatment $[23,24]$; PD-L1, however, is far from being devoid of problems.

\section{PD-L1 Limitations: PD-L1 as a Flawed Predictive Biomarker}

In order to better explain the limitations associated with PD-L1's capacity to predict response to immunotherapy, it can be useful to take into account the data from each ICI pivotal trial (Table 1).

In CheckMate 017, PD-L1 expression levels were found to be neither prognostic nor predictive of survival benefit, while in CheckMate 057, increasing PD-L1 expression levels were found to be associated with more favorable clinical outcomes $[25,26]$. In CheckMate 227, increasing PD-L1 expression levels were found to be associated with more favorable clinical outcomes; however, while the benefit was clear for PD-L1 expression levels $\geq 50 \%$, patients with PD-L1 expression levels $<1 \%$ presented comparable survival outcome to those with PD-L1 expression levels $\geq 1 \%$ and better survival outcomes than those with PD-L1 expression levels between 1-49\% [27]. In CheckMate 9LA, patients with PD-L1 expression levels $<1 \%$ presented comparable hazard ratios for death to those with PD-L1 expression levels $\geq 1 \%$ [28]. In KEYNOTE-042, increasing PD-L1 expression levels were found to be associated with more favorable clinical outcomes; this was the case for PD-L1 expression levels $\geq 1 \%, \geq 20 \%$ and $\geq 50 \%$; however, patients with PD-L1 expression levels between 1-49\% showed worst survival data than all the other subsets of patients [29]. On the other hand, in KEYNOTE-189 and in KEYNOTE-407, increasing PD-L1 expression levels were found to be associated with more favorable clinical outcomes [30,31]; similarly, in KEYNOTE-010, increasing PD-L1 expression levels were found to be associated with more favorable clinical outcomes [32]. In the OAK, IMpower110, IMpower130 and IMpower150 trials, increasing PD-L1 or IC expression levels were found to be associated with more favorable clinical outcomes; conversely, in the POPLAR study, patients with PD-L1 expression levels $\geq 1 \%$ had comparable survival outcomes to those with PD-L1 expression levels $\geq 50 \%$ and better survival outcomes than those with PD-L1 expression levels $\geq 5 \%$ [33-37]. 
Globally, considering all the above-mentioned data, it clearly appears that PD-L1 represents an indeed flawed predictive biomarker: while on the one hand, greater response rates and superior survival performances are linked to higher PD-L1 expression levels (especially for PD-L1 expression levels $\geq 50 \%$ ), on the other hand, patients with low or without PD-L1 expression can benefit greatly from ICI therapy, at times even more than patients with higher PD-L1 expression levels. In addition, while generally, patients with PD-L1 expression levels (especially if $\geq 50 \%$ ) experience the best clinical outcomes to ICI treatment, poor responses are reported. Two main reasons could lie behind the limitations of PD-L1 as a predictive biomarker for ICI treatment: firstly, the PD-1-PD-L1 axis only represents one of the several different immune checkpoints involved in cancer immune-mediated escape mechanisms; secondly, apart from immune checkpoints, the PD-1-PD-L1 axis fits into the extremely wider (and still poorly understood) context of tumor microenvironment $[38,39]$

\section{Emerging Biomarkers for the Selection of Advanced NSCLC-Affected Immunotherapy Patients}

Therefore, several different biomarkers are currently under investigation, in order to overcome PD-L1 limitations and to better guide ICI therapy in advanced NSCLC patients.

\section{1. $T M B$}

The tumor mutational burden (TMB) represents the amount of cancer genome mutations per DNA coding region; in preclinical and early clinical trials its high expression was associated to an independent from PD-L1 expression levels increased response to ICI treatment; the reason for these results could seemingly lie in the enhanced neoantigen expression caused by high mutational loads [40,41]. In the original design of the CheckMate 227 study, TMB was evaluated as a potential predictive biomarker. In this trial, 1189 naïve squamous and nonsquamous advanced NSCLC patients without genetic drivers and with PD-L1 expression levels $\geq 1 \%$ were randomized (1:1:1) to receive nivolumab + ipilimumab, histology-based chemotherapy, or nivolumab monotherapy, while 550 naïve squamous and nonsquamous advanced NSCLC patients without genetic drivers and with PD-L1 expression levels $<1 \%$ were randomized (1:1:1) to receive nivolumab + ipilimumab, histology-based chemotherapy, or nivolumab + histology-based chemotherapy; both subsets of patients were assessed for TMB expression. In high-TMB patients ( $\geq 10$ mutations per megabase), the nivolumab + ipilimumab association performed better than histology-based chemotherapy according to every prespecified outcome measure and most importantly independently from PD-L1 expression levels: ORR (objective response rate): $45.3 \%$ vs. $26.9 \%$, PFS (progression free survival): 7.2 months vs. 5.5 months, HR (hazard ratio) for disease progression or death: 0.58 [42]. Nonetheless, after a request by the FDA and the EMA-CHMP (EMA Committee for Medicinal Products for Human Use), OS (overall survival) data were disclosed, including both the high-TMB and the low-TMB ( $<10$ mutations per megabase) patients. As a consequence, the nivolumab + ipilimumab experimental combination proved to be superior to histology-based chemotherapy in both high-TMB patients (OS: 23.03 months vs. 16.72 months; HR: 0.77) and low-TMB patients (16.20 months vs. 12.42 months; HR: 0.78). Due to these data, TMB effectiveness and reliability as a predictive biomarker has been significantly attenuated, seemingly re-defining it as a prognostic biomarker $[43,44]$. Furthermore, the TMB was also investigated in a post hoc exploratory analysis comprising the data from KEYNOTE-010 (cohorts C and G), KEYNOTE-189 and KEYNOTE-407 trials, utilizing a cut-off of 175 mutations per exome; also in this analysis, no survival benefit was noted neither in terms of ORR nor in terms of PFS or OS for patients with a high TMB ( $\geq 175$ mutations per exome) [45].

\subsection{TILS}

$\mathrm{CD}^{+}, \mathrm{CD}^{+}$and $\mathrm{CD} 8^{+}$tumor infiltrating lymphocytes (TILS) are the main effectors of the ICI-mediated anticancer activity and higher levels of TILS are associated to a better prognosis in NSCLC patients [46]. However, enhanced TILS levels (in particular CD8 ${ }^{+}$ 
TILS) also seem to be linked superior responses to ICI therapy. In a recent trial, Uryvaev et coll. analyzed a subset of 26 advanced NSCLC patients, assessing CD4 ${ }^{+}$and CD8 ${ }^{+}$ TILS levels in tumors tissues: while CD8 ${ }^{+}$TILS levels $<886 / \mathrm{mm}^{2}$ were associated with lower response rates to anti PD-1 ICI therapy (16.7\% of treated patients), CD ${ }^{+}$TILS levels between $886-1899 / \mathrm{mm}^{2}$ were associated with superior response rates $(60 \%$ of treated patients); furthermore, $\mathrm{CD}^{+} / \mathrm{CD}^{+} \mathrm{TILS}$ ratios $<2$ were linked to lower response rates (13.3\% of treated patients), while $\mathrm{CD}^{+} / \mathrm{CD}^{+}$TILS ratios $>2$ were linked to superior response rates (43-50\% of treated patients) [47].

\subsection{NLR}

The neutrophil-to-lymphocyte ratio (NLR) is simply calculated by dividing the number of neutrophils by the number of lymphocytes after a blood sample; a neutrophil-rich TME is believed to promote tumor progression via the production of cytokines that enhance angiogenesis and inhibit cell death. In this vein, baseline increased NLR has proved to be a negative prognostic biomarker (in terms of inferior OS and PFS results) in advanced NSCLC patients treated with chemotherapy, immunotherapy or targeted therapy [48]; for example, in a very recent series of retrospective trials analyzing 784 and 132 advanced NSCLC patients with PD-L1 expression levels $\geq 50 \%$, Banna et coll. showed that an NLR $>4$ or $>5$, respectively, represents an independent negative prognostic factor also in this subset of patients $[49,50]$. Moreover, the NLR could also serve as a predictive biomarker for advanced NSCLC undergoing ICI treatment, according to several recent studies. In a recent retrospective trial, Bagley et coll. reviewed the medical records of 175 pretreated advanced NSCLC patients receiving subsequent-line nivolumab and evaluated their NLR adopting a $\geq 5$ / $<5$ cut-off; as a result, a baseline NLR $\geq 5$ proved to be associated with inferior survival outcomes when compared to a baseline NLR <5: PFS: 1.9 months vs. 2.8 months (HR for death or progression: 1.43), OS: 5.5 months vs. 8.4 months (HR for death: 2.07) [51]. Similarly, in another trial, Nakaya et coll. retrospectively evaluated 101 pretreated advanced NSCLC patients receiving subsequent-line nivolumab analyzing their NLR, employing a $\geq 3$ / <3 cut-off not only before ICI therapy, but also after 2 and 4 weeks after the first administration; as a result, not only the PFS data favored patients with low baseline NLR (3.4 months vs. 2.9 months), but they also favored patients with a low NLR at two weeks after treatment (5.3 months vs. 2.1 months) and at 4 weeks after treatment (5.3 months vs. 2.0 months) [52].

\section{4. $I L-8$}

Interleukine-8 (IL-8) is a pro-inflammatory chemokine overexpressed by tumor cells (often alongside its receptor, also known as IL-8R); the activation of the IL-8-IL-8R pathway promotes angiogenesis, proliferation, tumor cells survival, the formation of metastases as well as the creation of an immunosuppressive TME [53]. IL-8's possible predictive role with respect to ICI treatment is currently the subject of debate. In an interesting recent trial, Sanmamed et coll. analyzed 19 advanced NSCLC-affected pretreated patients receiving subsequent-line nivolumab or pembrolizumab, assessing serum IL-8 levels before ICI treatment and 2 and 4 weeks after the first administration. Interestingly, taking into account baseline levels, among the 12 responders, the median serum IL-8 levels declined when the patients presented the best response; at the same time, among the seven nonresponders, median serum IL-8 levels rose when they experienced a progression of disease, suggesting that variations of serum IL-8 levels could represent a predictive biomarker with reference to ICI treatment; on a side note, it is worth mentioning that when two patients showed radiological signs of progression that was confirmed to be a pseudoprogression at a later follow-up, a decrease in serum IL-8 levels was recorded [54].

\subsection{IDO1}

Indoleamine 2, 3-dioxygenases (IDO1) is an enzyme normally responsible for the conversion of tryptophan into kynurenine, whose metabolites exert an immunosuppressive 
role and contribute to immune tolerance; however, IDO1 levels can also be enhanced in several tumors, NSCLC included, leading to an immunosuppressive TME. In this vein, in an intriguing study by Botticelli et coll, the kynurenine/tryptophan ratio was assessed as a predictive biomarker with reference to ICI treatment. Considering 26 advanced NSCLCaffected patients, a statistically significant correlation ( $p$ : 0.017) was noted between a short time to the progression of disease ( $<3$ months) and higher kynurenine/tryptophan levels, while lower kynurenine/tryptophan levels were significantly linked to improved PFS and OS results ( $p: 0.018)$ [55]

\subsection{Microbiome and Antibiotic Treatment}

Preclinical and clinical trials have established that bacterial diversity in the context of gut microbiome plays an important role with respect to immune response against several different cancers, NSCLC included. In the same vein, pre-ICI therapy antibiotic treatment has been linked to decreased immunotherapy effectiveness in terms of PFS and OS, seemingly due to decreased gut bacteria diversity [56,57]. Therefore, gut microbiome is currently being assessed as a potential predictive biomarker. In a recent study by Hakozaki et al., baseline stool samples were collected from 70 advanced NSCLC patients before administering first or subsequent-line ICI monotherapy, then the median clinical outcome measures were reported: mORR: 34\%, mPFS: 5.2 months, mOS: 15.2 months. On the one hand, patients who received pre-immunotherapy antibiotic treatment presented a reduced gut bacteria diversity with a particularly diminished representation of Ruminococcaceae UCG 13 and Agathobacter, resulting in worse OS results when compared to patients who did not receive pre-immunotherapy antibiotic treatment: 12.1 months vs. 16.1 months; on the other hand, patients who did not receive pre-immunotherapy antibiotic treatment presented a superior gut bacteria diversity with an overrepresentation of Ruminococcaceae UCG 13 and Agathobacter, resulting in better ORR (>34\%), PFS (>6 months) and OS (>16 months) [58]

\subsection{Immune Gene Signatures}

An immune gene signature can be defined as the combination of all the alterations of the immune-related gene expression $[59,60]$. In this vein, several different immune gene expressions are presently being investigated in order to assess if they can predict response to immunotherapy. In a very recent and interesting study, Hwang et al. collected tumor samples from 21 advanced NSCLC-affected ICI-treated patients, proving that patients harboring an M1 signature (including the CBLB, CCR7, CD27, CD48, FOXO1, FYB, HLA-B, HLA-G, IFIH1, IKZF4, LAMP3, NFKBIA, SAMHD1 genes) or a peripheral T signature (including the HLA-DOA, GPR18, STAT1 genes), as well as those expressing CD137 and PSMB9 mRNAs showed superior survival performances when compared to those who did not and that this immune gene signature proved to be far more predictive of ICI response than PD-L1, TMB or TILS [61].

\subsection{Established and Emerging Mutations}

According to the more recent and larger literature data, classic driver mutations (EGFR, ALK, BRAF, ROS1, MET, KRAS, HER 2, RET) are considered negative predictive biomarkers, due to their association with very poor response to ICI treatment and thus, immunotherapy should only be considered after the failure of all the other available therapies $[62,63]$. Furthermore, this association also seems to apply to more uncommon mutations, e.g., STK11. Taking into account both the available literature data and the data coming from a very large and recent trial by Ricciuti et coll., it appears that STK11 mutations represent a negative predictive biomarker in ICI-treated advanced NSCLC-affected patients in terms of poor ORR, PFS and OS when associated to a KRAS co-mutation, while they seem to be uninfluential when associated to a wild type KRAS gene $[64,65]$. 


\section{Conclusions and Future Perspectives}

Immunotherapy in the form of ICIs has revolutionized advanced NSCLC treatment algorithms, with ICI-containing combination treatments being the latest addition to approved regimens $[66,67]$. However, if on the one hand treatment strategies have consistently evolved since the first FDA-approved ICI in this subset of patients (nivolumab, 2015) [68], on the other hand, our biomarker availability still lags behind, with PD-L1 still representing the only routinely assessed and validated apart from genetic drivers testing; moreover, taking into account the different PD-L1 tests used, it is worth mentioning that while the PD-L1 IHC 22C3 pharmDx and the PD-L1 IHC 28-8 pharmDx tests present a very high concordance, the same does not apply to the ventana PD-L1 (sp142), due to its different staining properties [69]. Nevertheless, as the above-mentioned data extensively show, there is a growing and thriving interest towards emerging predictive biomarkers, that in a near future will undoubtedly help us to further tailor treatments, optimizing current treatment options and maximizing survival results. In this vein, further and larger studies will be needed in order to validate, standardize and shift these experimental biomarkers into clinical practice.

Author Contributions: Conceptualization: L.D.G. and D.R.; resources: L.D.G. and D.R.; writingoriginal draft preparation: L.D.G. and D.R.; writing-review and editing: L.D.G., D.R., C.B., A.L., R.C., V.D. and G.S.; supervision: D.R.; project administration: D.R. All authors have read and agreed to the published version of the manuscript.

Funding: This research received no external funding.

Institutional Review Board Statement: Not applicable.

Informed Consent Statement: Not applicable.

Data Availability Statement: Not applicable.

Conflicts of Interest: The authors declare no conflict of interest.

\section{References}

1. Spiro, S.G.; Silvestri, G.A. One Hundred Years of Lung Cancer. Am. J. Respir. Crit. Care Med. 2005, 172, 523-529. [CrossRef]

2. Comella, P.; Campano, O.; Frasci, G.; De Cataldis, G.; Panza, N.; Cioffi, R.; Curcio, C.; Belli, M.; Bianco, A.; Ianniello, G.; et al. Cisplatin/carboplatin + etoposide + vinorelbine in advanced non-small-cell lung cancer: A multicentre randomised trial. Br. J. Cancer 1996, 74, 1805-1811. [CrossRef]

3. Kosmidis, P. Chemotherapy in NSCLC: Historical review. Lung Cancer 2002, 38, 19-22. [CrossRef]

4. Toschi, L.; Rossi, S.; Finocchiaro, G.; Santoro, A. Non-small cell lung cancer treatment (r)evolution: Ten years of advances and more to come. Ecancermedicalscience 2017, 11, 787. [CrossRef] [PubMed]

5. Alexander, M.; Kim, S.Y.; Cheng, H. Update 2020: Management of Non-Small Cell Lung Cancer. Lung 2020, $198,897-907$. [CrossRef] [PubMed]

6. Onoi, K.; Chihara, Y.; Uchino, J.; Shimamoto, T.; Morimoto, Y.; Iwasaku, M.; Kaneko, Y.; Yamada, T.; Takayama, K. Immune Checkpoint Inhibitors for Lung Cancer Treatment: A Review. J. Clin. Med. 2020, 9, 1362. [CrossRef] [PubMed]

7. Planchard, D.; Popat, S.; Kerr, K.; Novello, S.; Smit, E.F.; Faivre-Finn, C.; Mok, T.S.; Reck, M.; Van Schil, P.E.; Hellmann, M.D.; et al. Metastatic non-small cell lung cancer: ESMO Clinical Practice Guidelines for diagnosis, treatment and follow-up. Ann. Oncol. 2018, 29 (Suppl. 4), iv192-iv237. Available online: https:/ /www.esmo.org/content/download/347819/6934778/1/ESMO-CPGmNSCLC-15SEPT2020.pdf (accessed on 31 March 2021). [CrossRef]

8. Hanna, N.H.; Schneider, B.J.; Temin, S.; Baker, S.; Brahmer, J.; Ellis, P.M.; Gaspar, L.E.; Haddad, R.Y.; Hesketh, P.J.; Jain, D.; et al. Therapy for Stage IV Non-Small-Cell Lung Cancer without Driver Alterations: ASCO and OH (CCO) Joint Guideline Update. J. Clin. Oncol. 2020, 38, 1608-1632. [CrossRef] [PubMed]

9. NCCN Clinical Practice Guidelines in Oncology: Non-Small Cell Lung Cancer. Available online: https://www.nccn.org/ professionals/physician_gls/pdf/nscl.pdf (accessed on 31 March 2021).

10. FDA Approves Nivolumab Plus Ipilimumab for First-Line mNSCLC (PD-L1 Tumor Expression $\geq 1 \%$ ). Available online: https: / / www.fda.gov/drugs/drug-approvals-and-databases/fda-approves-nivolumab-plus-ipilimumab-first-line-mnsclcpd-11-tumor-expression-1 (accessed on 31 March 2021).

11. FDA Approves Nivolumab Plus Ipilimumab and Chemotherapy for First-Line Treatment of Metastatic NSCLC. Available online: https: / / www.fda.gov/drugs/drug-approvals-and-databases / fda-approves-nivolumab-plus-ipilimumab-and-chemotherapyfirst-line-treatment-metastatic-nsclc (accessed on 31 March 2021). 
12. Kazandjian, D.; Suzman, D.L.; Blumenthal, G.; Mushti, S.; He, K.; Libeg, M.; Keegan, P.; Pazdur, R. FDA Approval Summary: Nivolumab for the Treatment of Metastatic Non-Small Cell Lung Cancer with Progression on or After Platinum-Based Chemotherapy. Oncologist 2016, 21, 634-642. [CrossRef]

13. FDA Expands Pembrolizumab Indication for First-Line Treatment of NSCLC (TPS $\geq 1 \%$ ). Available online: https: / /www.fda. gov/drugs/fda-expands-pembrolizumab-indication-first-line-treatment-nsclc-tps-1 (accessed on 31 March 2021).

14. Pai-Scherf, L.; Blumenthal, G.M.; Li, H.; Subramaniam, S.; Mishra-Kalyani, P.S.; He, K.; Zhao, H.; Yu, J.; Paciga, M.; Goldberg, K.B.; et al. FDA Approval Summary: Pembrolizumab for Treatment of Metastatic Non-Small Cell Lung Cancer: First-Line Therapy and Beyond. Oncologist 2017, 22, 1392-1399. [CrossRef] [PubMed]

15. FDA Grants Regular Approval for Pembrolizumab in Combination with Chemotherapy for First-Line Treatment of Metastatic Nonsquamous NSCLC. Available online: https:/ / www.fda.gov/drugs/resources-information-approved-drugs/fda-grantsregular-approval-pembrolizumab-combination-chemotherapy-first-line-treatment-metastatic (accessed on $31 \mathrm{March} 2021$ ).

16. FDA Approves Pembrolizumab in Combination with Chemotherapy for First-Line Treatment of Metastatic Squamous NSCLC. Available online: https:/ / www.fda.gov/drugs/fda-approves-pembrolizumab-combination-chemotherapy-first-line-treatmentmetastatic-squamous-nsclc (accessed on 31 March 2021).

17. FDA Approves Atezolizumab for First-Line Treatment of Metastatic NSCLC with High PD-L1 Expression. Available online: https: / www.fda.gov/drugs/resources-information-approved-drugs/fda-approves-atezolizumab-first-line-treatmentmetastatic-nsclc-high-pd-11-expression (accessed on 31 March 2021).

18. FDA Approves Atezolizumab with Nab-Paclitaxel and Carboplatin for Metastatic NSCLC without EGFR/ALK Aberrations. Available online: https:/ / www.fda.gov/drugs/resources-information-approved-drugs/fda-approves-atezolizumab-nab-paclitaxeland-carboplatin-metastatic-nsclc-without-egfralk (accessed on 31 March 2021).

19. FDA Approves Atezolizumab with Chemotherapy and Bevacizumab for First-Line Treatment of Metastatic Non-Squamous NSCLC. Available online: https:/ / www.fda.gov/drugs/fda-approves-atezolizumab-chemotherapy-and-bevacizumab-firstline-treatment-metastatic-non-squamous (accessed on 31 March 2021).

20. Atezolizumab (TECENTRIQ). Available online: https://www.fda.gov/drugs/resources-information-approved-drugs/ atezolizumab-tecentriq (accessed on 31 March 2021).

21. Han, Y.; Liu, D.; Li, L. PD-1/PD-L1 pathway: Current researches in cancer. Am. J. Cancer Res. 2020, 10, 727-742. [PubMed]

22. Rocco, D.; Della Gravara, L.; Avellino, A.; Montesarchio, V.; Battiloro, C. Immunotherapy as a targeted therapy in non-small cell lung cancer. Transl. Cancer Res. 2018, 8, S70-S75. [CrossRef]

23. Twomey, J.D.; Zhang, B. Cancer Immunotherapy Update: FDA-Approved Checkpoint Inhibitors and Companion Diagnostics. AAPS J. 2021, 23, 1-11. [CrossRef]

24. Davis, A.A.; Patel, V.G. The role of PD-L1 expression as a predictive biomarker: An analysis of all US Food and Drug Administration (FDA) approvals of immune checkpoint inhibitors. J. Immunother. Cancer 2019, 7, 1-8. [CrossRef] [PubMed]

25. Brahmer, J.; Reckamp, K.L.; Baas, P.; Crinò, L.; Eberhardt, W.E.; Poddubskaya, E.; Antonia, S.; Pluzanski, A.; Vokes, E.E.; Holgado, E.; et al. Nivolumab versus Docetaxel in Advanced Squamous-Cell Non-Small-Cell Lung Cancer. N. Engl. J. Med. 2015, 373, 123-135. [CrossRef]

26. Borghaei, H.; Paz-Ares, L.; Horn, L.; Spigel, D.R.; Steins, M.; Ready, N.E.; Chow, L.Q.; Vokes, E.E.; Felip, E.; Holgado, E.; et al. Nivolumab versus Docetaxel in Advanced Nonsquamous Non-Small-Cell Lung Cancer. N. Engl. J. Med. 2015, 373, 1627-1639. [CrossRef] [PubMed]

27. Hellmann, M.D.; Paz-Ares, L.; Caro, R.B.; Zurawski, B.; Kim, S.-W.; Costa, E.C.; Park, K.; Alexandru, A.; Lupinacci, L.; De la Mora, J.E.; et al. Nivolumab plus ipilimumab in advanced non-small-cell lung cancer. N. Engl. J. Med. 2019, 381, $2020-2031$. [CrossRef]

28. Paz-Ares, L.; Ciuleanu, T.-E.; Cobo, M.; Schenker, M.; Zurawski, B.; Menezes, J.; Richardet, E.; Bennouna, J.; Felip, E.; Juan-Vidal, O.; et al. First-line nivolumab plus ipilimumab combined with two cycles of chemotherapy in patients with nonsmall-cell lung cancer (CheckMate 9LA): An international, randomised, open-label, phase 3 trial. Lancet Oncol. 2021, 22, 198-211. [CrossRef]

29. Mok, T.S.K.; Wu, Y.-L.; Kudaba, I.; Kowalski, D.M.; Cho, B.C.; Turna, H.Z.; Castro, G.; Srimuninnimit, V.; Laktionov, K.K.; Bondarenko, I.; et al. Pembrolizumab versus chemotherapy for previously untreated, PD-L1-expressing, locally advanced or metastatic non-small-cell lung cancer (KEYNOTE-042): A randomised, open-label, controlled, phase 3 trial. Lancet 2019, 393, 1819-1830. [CrossRef]

30. Gandhi, L.; Rodríguez-Abreu, D.; Gadgeel, S.; Esteban, E.; Felip, E.; De Angelis, F.; Domine, M.; Clingan, P.; Hochmair, M.J.; Powell, S.F.; et al. Pembrolizumab plus Chemotherapy in Metastatic Non-Small-Cell Lung Cancer. N. Engl. J. Med. 2018, 378, 2078-2092. [CrossRef]

31. Paz-Ares, L.; Luft, A.; Vicente, D.; Tafreshi, A.; Gümüş, M.; Mazières, J.; Hermes, B.; Şenler, F.; Çay; Csőszi, T.; Fülöp, A.; et al. Pembrolizumab plus Chemotherapy for Squamous Non-Small-Cell Lung Cancer. N. Engl. J. Med. 2018, 379, 2040-2051. [CrossRef]

32. Herbst, R.S.; Baas, P.; Kim, D.-W.; Felip, E.; Perez-Gracia, J.L.; Han, J.-Y.; Molina, J.; Kim, J.-H.; Arvis, C.D.; Ahn, M.-J.; et al. Pembrolizumab versus docetaxel for previously treated, PD-L1-positive, advanced non-small-cell lung cancer (KEYNOTE-010): A randomised controlled trial. Lancet 2016, 387, 1540-1550. [CrossRef] 
33. Rittmeyer, A.; Barlesi, F.; Waterkamp, D.; Park, K.; Ciardiello, F.; von Pawel, J.; Gadgeel, S.M.; Hida, T.; Kowalski, D.; Dols, M.C.; et al. Atezolizumab versus docetaxel in patients with previously treated non-small-cell lung cancer (OAK): A phase 3, open-label, multicentre randomised controlled trial. Lancet 2017, 389, 255-265. [CrossRef]

34. Mazieres, J.; Rittmeyer, A.; Gadgeel, S.; Hida, T.; Gandara, D.R.; Cortinovis, D.L.; Barlesi, F.; Yu, W.; Matheny, C.; Ballinger, M.; et al. Atezolizumab Versus Docetaxel in Pretreated Patients with NSCLC: Final Results from the Randomized Phase 2 POPLAR and Phase 3 OAK Clinical Trials. J. Thorac. Oncol. 2021, 16, 140-150. [CrossRef] [PubMed]

35. Herbst, R.S.; Giaccone, G.; De Marinis, F.; Reinmuth, N.; Vergnenegre, A.; Barrios, C.H.; Morise, M.; Felip, E.; Andric, Z.; Geater, S.; et al. Atezolizumab for First-Line Treatment of PD-L1-Selected Patients with NSCLC. N. Engl. J. Med. 2020, 383, 1328-1339. [CrossRef] [PubMed]

36. West, H.; McCleod, M.; Hussein, M.; Morabito, A.; Rittmeyer, A.; Conter, H.J.; Kopp, H.-G.; Daniel, D.; McCune, S.; Mekhail, T.; et al. Atezolizumab in combination with carboplatin plus nab-paclitaxel chemotherapy compared with chemotherapy alone as first-line treatment for metastatic non-squamous non-small-cell lung cancer (IMpower130): A multicentre, randomised, open-label, phase 3 trial. Lancet Oncol. 2019, 20, 924-937. [CrossRef]

37. Socinski, M.A.; Jotte, R.M.; Cappuzzo, F.; Orlandi, F.; Stroyakovskiy, D.; Nogami, N.; Rodríguez-Abreu, D.; Moro-Sibilot, D.; Thomas, C.A.; Barlesi, F. Atezolizumab for First-Line Treatment of Metastatic Nonsquamous NSCLC. N. Engl. J. Med. 2018, 378, 2288-2301. [CrossRef]

38. He, X.; Xu, C. Immune checkpoint signaling and cancer immunotherapy. Cell Res. 2020, 30, 660-669. [CrossRef]

39. Baghban, R.; Roshangar, L.; Jahanban-Esfahlan, R.; Seidi, K.; Ebrahimi-Kalan, A.; Jaymand, M.; Kolahian, S.; Javaheri, T.; Zare, P. Tumor microenvironment complexity and therapeutic implications at a glance. Cell Commun. Signal. 2020, 18, 1-19. [CrossRef]

40. Greillier, L.; Tomasini, P.; Barlesi, F. The clinical utility of tumor mutational burden in non-small cell lung cancer. Transl. Lung Cancer Res. 2018, 7, 639-646. [CrossRef]

41. Sholl, L.M.; Hirsch, F.R.; Hwang, D.; Botling, J.; Lopez-Rios, F.; Bubendorf, L.; Mino-Kenudson, M.; Roden, A.C.; Beasley, M.B.; Borczuk, A.; et al. The Promises and Challenges of Tumor Mutation Burden as an Immunotherapy Biomarker: A Perspective from the International Association for the Study of Lung Cancer Pathology Committee. J. Thorac. Oncol. 2020, 15, 1409-1424. [CrossRef]

42. Hellmann, M.D.; Ciuleanu, T.-E.; Pluzanski, A.; Lee, J.S.; Otterson, G.A.; Audigier-Valette, C.; Minenza, E.; Linardou, H.; Burgers, S.; Salman, P.; et al. Nivolumab plus Ipilimumab in Lung Cancer with a High Tumor Mutational Burden. N. Engl. J. Med. 2018, 378, 2093-2104. [CrossRef] [PubMed]

43. BMS Press Release. Bristol-Myers Squibb Provides Update on the Ongoing Regulatory Review of Opdivo Plus Low-Dose Yervoy in First-Line Lung Cancer Patients with Tumor Mutational Burden $\geq 10$ mut/Mb. Available online: https://news.bms.com/pressrelease/corporatefinancial-news/bristol-myers-squibb-provides-update-ongoing-regulatory-review (accessed on 31 March 2021).

44. Addeo, A.; Banna, G.L.; Weiss, G.J. Tumor Mutation Burden-From Hopes to Doubts. JAMA Oncol. 2019, 5, 934-935. [CrossRef]

45. Paz-Ares, L.; Langer, C.J.; Novello, S.; Halmos, B.; Cheng, Y.; Gadgeel, S.M.; Hui, R.; Sugawara, S.; Borghaei, H.; Cristescu, R.; et al . LBA80Pembrolizumab (pembro) plus platinum-based chemothera-py(chemo) for metastatic NSCLC: Tissue TMB (tTMB) and outcomes in KEYNOTE-021, 189, and 407. Ann. Oncol. 2019, 30, v917-v918. [CrossRef]

46. Zeng, D.; Yu, Y.-F.; Ou, Q.-Y.; Li, X.-Y.; Zhong, R.-Z.; Xie, C.-M.; Hu, Q.-G. Prognostic and predictive value of tumor-infiltrating lymphocytes for clinical therapeutic research in patients with non-small cell lung cancer. Oncotarget 2016, 7, 13765-13781. [CrossRef]

47. Uryvaev, A.; Passhak, M.; Hershkovits, D.; Sabo, E.; Bar-Sela, G. The role of tumor-infiltrating lymphocytes (TILs) as a predictive biomarker of response to anti-PD1 therapy in patients with metastatic non-small cell lung cancer or metastatic melanoma. Med. Oncol. 2018, 35, 25. [CrossRef]

48. Wang, Z.; Zhan, P.; Lv, Y.; Shen, K.; Wei, Y.; Liu, H.; Song, Y. Prognostic role of pretreatment neutrophil-to-lymphocyte ratio in non-small cell lung cancer patients treated with systemic therapy: A meta-analysis. Transl. Lung Cancer Res. 2019, 8, 214-226. [CrossRef] [PubMed]

49. Banna, G.; Cortellini, A.; Cortinovis, D.; Tiseo, M.; Aerts, J.; Barbieri, F.; Giusti, R.; Bria, E.; Grossi, F.; Pizzutilo, P.; et al. The lung immuno-oncology prognostic score (LIPS-3): A prognostic classification of patients receiving first-line pembrolizumab for PD-L1 $\geq 50 \%$ advanced non-small-cell lung cancer. ESMO Open 2021, 6, 100078. [CrossRef] [PubMed]

50. Banna, G.L.; Signorelli, D.; Metro, G.; Galetta, D.; De Toma, A.; Cantale, O.; Banini, M.; Friedlaender, A.; Pizzutillo, P.; Garassino, M.C.; et al. Neutrophil-to-lymphocyte ratio in combination with PD-L1 or lactate dehydrogenase as biomarkers for high PD-L1 non-small cell lung cancer treated with first-line pembrolizumab. Transl. Lung Cancer Res. 2020, 9, $1533-1542$. [CrossRef] [PubMed]

51. Bagley, S.J.; Kothari, S.; Aggarwal, C.; Bauml, J.M.; Alley, E.W.; Evans, T.L.; Kosteva, J.A.; Ciunci, C.A.; Gabriel, P.E.; Thompson, J.C.; et al. Pretreatment neutrophil-to-lymphocyte ratio as a marker of outcomes in nivolumab-treated patients with advanced non-small-cell lung cancer. Lung Cancer 2017, 106, 1-7. [CrossRef] [PubMed]

52. Nakaya, A.; Kurata, T.; Yoshioka, H.; Takeyasu, Y.; Niki, M.; Kibata, K.; Satsutani, N.; Ogata, M.; Miyara, T.; Nomura, S. Neutrophil-to-lymphocyte ratio as an early marker of outcomes in patients with advanced non-small-cell lung cancer treated with nivolumab. Int. J. Clin. Oncol. 2018, 23, 634-640. [CrossRef] [PubMed]

53. Waugh, D.J.; Wilson, C. The Interleukin-8 Pathway in Cancer. Clin. Cancer Res. 2008, 14, 6735-6741. [CrossRef] [PubMed] 
54. Sanmamed, M.F.; Perez-Gracia, J.L.; Schalper, K.A.; Fusco, J.P.; Gonzalez, A.; Rodriguez-Ruiz, M.E.; Oñate, C.; Perez, G.; Alfaro, C.; Martín-Algarra, S.; et al. Changes in serum interleukin-8 (IL-8) levels reflect and predict response to anti-PD-1 treatment in melanoma and non-small-cell lung cancer patients. Ann. Oncol. 2017, 28, 1988-1995. [CrossRef]

55. Botticelli, A.; Cerbelli, B.; Lionetto, L.; Zizzari, I.; Salati, M.; Pisano, A.; Federica, M.; Simmaco, M.; Nuti, M.; Marchetti, P. Can IDO activity predict primary resistance to anti-PD-1 treatment in NSCLC? J. Transl. Med. 2018, 16, 1-6. [CrossRef] [PubMed]

56. Routy, B.; Le Chatelier, E.; DeRosa, L.; Duong, C.P.M.; Alou, M.T.; Daillère, R.; Fluckiger, A.; Messaoudene, M.; Rauber, C.; Roberti, M.P.; et al. Gut microbiome influences efficacy of PD-1-based immunotherapy against epithelial tumors. Science 2018, 359, 91-97. [CrossRef] [PubMed]

57. Botticelli, A.; Vernocchi, P.; Marini, F.; Quagliariello, A.; Cerbelli, B.; Reddel, S.; Del Chierico, F.; Di Pietro, F.; Giusti, R.; Tomassini, A.; et al. Gut metabolomics profiling of non-small cell lung cancer (NSCLC) patients under immunotherapy treatment. J. Transl. Med. 2020, 18, 49. [CrossRef] [PubMed]

58. Hakozaki, T.; Richard, C.; Elkrief, A.; Hosomi, Y.; Benlaïfaoui, M.; Mimpen, I.; Terrisse, S.; DeRosa, L.; Zitvogel, L.; Routy, B.; et al. The Gut Microbiome Associates with Immune Checkpoint Inhibition Outcomes in Patients with Advanced Non-Small Cell Lung Cancer. Cancer Immunol. Res. 2020, 8, 1243-1250. [CrossRef] [PubMed]

59. Chibon, F. Cancer gene expression signatures-The rise and fall? Eur. J. Cancer 2013, 49, 2000-2009. [CrossRef] [PubMed]

60. Liu, Y. A global immune gene expression signature for human cancers. Oncotarget 2019, 10, 1993-2005. [CrossRef]

61. Hwang, S.; Kwon, A.-Y.; Jeong, J.-Y.; Kim, S.; Kang, H.; Park, J.; Kim, J.-H.; Han, O.J.; Lim, S.M.; An, H.J. Immune gene signatures for predicting durable clinical benefit of anti-PD-1 immunotherapy in patients with non-small cell lung cancer. Sci. Rep. 2020, 10, 1-10. [CrossRef]

62. Mazieres, J.; Drilon, A.; Lusque, A.; Mhanna, L.; Cortot, A.; Mezquita, L.; Thai, A.; Mascaux, C.; Couraud, S.; Veillon, R.; et al. Immune checkpoint inhibitors for patients with advanced lung cancer and oncogenic driver alterations: Results from the IMMUNOTARGET registry. Ann. Oncol. 2019, 30, 1321-1328. [CrossRef] [PubMed]

63. Mhanna, L.; Guibert, N.; Milia, J.; Mazieres, J. When to Consider Immune Checkpoint Inhibitors in Oncogene-Driven Non-Small Cell Lung Cancer? Curr. Treat. Opt. Oncol. 2019, 20, 60. [CrossRef] [PubMed]

64. Torralvo, J.; Friedlaender, A.; Achard, V.; Addeo, A. The Activity of Immune Checkpoint Inhibition in KRAS Mutated Non-small Cell Lung Cancer: A Single Centre Experience. Cancer Genom. Proteom. 2019, 16, 577-582. [CrossRef] [PubMed]

65. Ricciuti, B.; Arbour, K.C.; Lin, J.J.; Vokes, N.; Hoojghan, A.V.; Li, Y.Y.; Cherniack, A.D.; Recondo, G.; Lamberti, G.; Venkatraman, D.; et al. Effect of STK11 mutations on efficacy of PD-1 inhibition in non-small cell lung cancer (NSCLC) and dependence on KRAS mutation status. J. Clin. Oncol. 2020, 38, e15113. [CrossRef]

66. Rocco, D.; Della Gravara, L.; Gridelli, C. The New Immunotherapy Combinations in the Treatment of Advanced Non-Small Cell Lung Cancer: Reality and Perspectives. Curr. Clin. Pharmacol. 2020, 15, 11-19. [CrossRef]

67. Rocco, D.; Della Gravara, L.; Battiloro, C.; Gridelli, C. The role of combination chemo-immunotherapy in advanced non-small cell lung cancer. Expert Rev. Anticancer Ther. 2019, 19, 561-568. [CrossRef]

68. FDA Approves First Immunotherapy Treatment for Lung Cancer. Available online: https://www.cancer.gov/news-events/ cancer-currents-blog/2015/fda-opdivo (accessed on 31 March 2021).

69. Lantuejoul, S.; Damotte, D.; Hofman, V.; Adam, J. Programmed death ligand 1 immunohistochemistry in non-small cell lung carcinoma. J. Thorac. Dis. 2019, 11, S89-S101. [CrossRef] 